\title{
Obituaries
}

Obituaries should be submitted by email to Jadene Doak at jadene.doak@springernature.com

All submitted obituaries should be 400 words maximum in length (apart from obituaries for past presidents of the BDA where the length should be 800 words).

Content of the obituary is down to the individual author, and the approval of the family should be given for the obituary prior to submission to the BDJ.

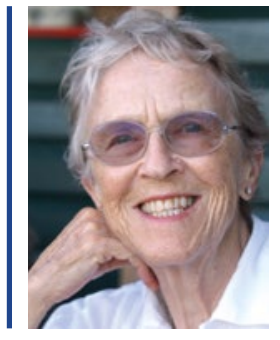

Pamela Le Couteur

1926-2019

Pamela Le Couteur qualified in dentistry from Melbourne University, Australia in 1948. With her husband Boyce, she developed an innovative combined rural general dental and medical practice in Port Fairy, Victoria. As the first female dentist in the area, Pamela was aware that she had to gain the confidence of the community. She quickly became the favoured dentist for children, and continued to champion their needs throughout her career.

Emigrating to England in 1960, Pamela was initially employed in the school dental service based at Farnborough. Wishing to keep up-todate in paediatric dentistry and public health, she joined the International Association of Dentistry for Children and contacted Professor Winter at the Eastman Dental Hospital, organising a week's refresher course every year. This was typical of Pamela; years ahead of her time in continuing professional development. In 1978 she became a member of the executive committee for the British Society of Dentistry for the Handicapped.

Having completed her Diploma in Dental Public Health, Pamela became assistant Area Dental Officer for Community Dental Services, initially in Berkshire and then in Hillingdon Dental Health Authority.

Pamela was a founding member of the Hampshire branch of the British Society of Paediatric Dentistry. As an active, effective and conscientious member of the Society at both branch and national level, she contributed to its development. From 1984 to 1991, Pamela was a member of the Executive Committee, holding posts including National Honorary Treasurer (1984-87), before becoming the first member of the Community Dental Service to be appointed President (1989-90).

For nearly 30 years following her retirement, Pamela continued to support paediatric dentistry while pursuing her interests in the arts and sciences. In 1991, she trained as part of the first contingent of volunteer guides at Kew Gardens, where she was also a patron and an enthusiastic supporter of the scientific work.

Throughout her long and active adult life Pamela was a powerful support and advocate for her family and friends, and for the careers of the many colleagues she felt privileged to work alongside.

She died of complications after emergency abdominal surgery, on 29 December 2019. She is survived by her two daughters, both doctors, and five grandchildren.

J. J. Murray, A. Le Couteur, C. Le Couteur

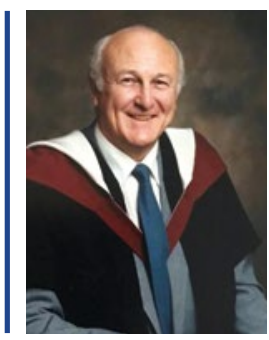

\section{Graham Charlton}

1928-2020

Graham was born on 15 October 1928 in Newbiggin by the Sea, Northumberland. After a couple of years teaching art, woodwork and games in Morpeth, Graham got a place in 1952 at the Dental School, Kings College, Durham University, situated in Newcastle-upon-Tyne, then thriving under the Deanship of Sir Robert Bradlaw.

Graham took an active role in student sports and politics, collecting several medals for academic achievement. After graduation BDS 1958 he became a partner in a general dental practice in Torquay, Devon, beginning to specialise in crown and bridge work. From 1964 Graham returned to academic life at
Bristol University teaching conservative dentistry, graduating MDS 1970 which, in addition to being a higher research degree, included a clinical component accepted by the Royal Colleges as an equivalent to the FDSRCS for the award of consultant status. Graham then became the Consultant Senior Lecturer in Conservative Dentistry, and later Clinical Dean while also researching the design of post-retained porcelain crowns leading to the integrated stainless steel Charlton Post and Core which he continued to refine and market successfully.

He often referred to his days at Bristol as the happiest in his life, living just outside the city in the beautiful countryside of Backwell with wife Stella and three children. In 1978, taking up the chair at Edinburgh University, and also becoming Dean of Dentistry, he again encouraged students to pursue excellence in their work.

Standing out as not just a brilliant clinician, he also drew on his teaching education to put his expertise across to students in an inspiring and lucid manner. Having 'come up through the ranks' he brought a unique individuality of thought and action which set him apart from most of his academic colleagues. He distinguished himself in having all the right qualities for the job and consequently scaled the heights of academic and practical dentistry. He developed the concepts of full gold crowns with reduced occlusal surface width and the ideal hygienic bridge design, and is also remembered for his whistle stop tours of the UK to give postgraduate lectures on advanced restorative dentistry.

In 1992 Graham retired and moved to Bearsden near Glasgow and eventually to York after a gap of fifty years. In 2005 Stella died. From 2013 he lived in residential care in Newcastle-upon-Tyne where he died on 1 February 2020 after a series of strokes.

Geoffrey van Beek, Bruce Charlton and Ken Marshall 